\title{
A Study of Social Realism in Kamala Markandaya's Nectare in a Sieve
}

\author{
Dr. S. Shanmugam \\ Assistant Professor Of English Cum Principal Sri Vidya Mandir College Of Arts And Science, Neikkarapatty, \\ Salem-636 010, Tamil Nadu, India.
}

\begin{abstract}
In our day-to-day life, everyone is facing many problems. Facing the problems is not important, but sustaining it very important. Every newspaper is coming out every day at least with a suicide. Kamala Markandaya's contribution is different, because her characters try to survive in every angle. Kamala Markandaya is an Indo-Anglian novelist. She has also studied the fatalism of the Indians and their passive acceptance of the given lot. Human relationship, especially the husband and wife relationship which causes much maladjustment leading to the disintegration of the family are also examined. Kamala Markandaya's novels are complex work of art and it is possible to read them on several levels. She has deftly delineated fully developed and charming character in her novels. The people most respected in Markandaya's world are those who are loyal, vital, sincere and compassionate. Her characters are devoid of individuality; for instance, in Nectar in a Sieve Rukmani and Nathan are representatives of uprooted peasants. Like the Shakespearean comedy, Kamala Markandaya's fiction is a woman's world. A fine feminine sensibility pervades her world of fiction. This fatalism and spirit of calm acceptance are seen clearly in Nectar in a Sieve in the lives of the central character. Nathan and Rukmani silently suffer what life inflicts upon them. They do not grumble or complain, but accept silently. Mutual love, trust, sympathy, reconciliation and co-operation are the cures for all social evils. Her novel, the rural novel, the domestic novel, and psychological novel establish her true merit as a social critic. The rural, social and moral picture of modern India that emerges from them serves as an eyeopener to the various faults and flaws found in it. It makes an impassioned plea for practising the nobler values of love, kindness humanity, sympathy, understanding and friendship in their life. Thus giving the persons in ideal human conduct, and laying the foundations of a better and jester and social order in which all strife, misunderstanding, hatred, jealousy, cruelty, enmity, suffering and injustice will yield place to the greatest happiness. Besides, this novel is a representative of her expressions of social condition. Her manifold virtues have made her a great novelist.
\end{abstract}

In our day-to-day life, everyone is facing many problems. Facing the problems is not important, but sustaining it very important. Every newspaper is coming out every day at least with a suicide. Kamala Markandaya's contribution is different, because her characters try to survive in every angle.

Kamala Markandaya is an Indo-Anglian novelist. She has also studied the fatalism of the Indians and their passive acceptance of the given lot. Human relationship, especially the husband and wife relationship which causes much maladjustment leading to the disintegration of the family are also examined with help of Social Realism. Kamala Markandaya's novels are complex work of art and it is possible to read them on several levels. She has deftly delineated fully developed and charming character in her novels. The people most respected in Markandaya's world are those, who are loyal, vital, sincere and compassionate.

She has been a laurel both in India and abroad. Dr. A.V. Krishna Rao opines that Kamala Markandaya's novels, in comparison with those of her contemporary woman writers, seem to be more fully reflective of the awakened feminine sensibility in modern India as she attempts to project the image of the changing traditional society. Kamala Markandaya's treatment of Indian rural life is comprehensive and allembracing. It is realistic and trustful. Through her treatment, she has focused attention on the wretched. Plight of the poor and the destitute and has shown a way of life remarkable for its heroic endurance and innate goodness. Nectar in a Sieve deals with the peasants and their activities, problems and anxieties, hopes and expectations, and joys and sorrows. It is therefore natural to find in it an emphasis on rural ethos and rural value system. Dr.K.R.Srinivasa Iyengar says, "women are natural story-tellers!" (435).

Kamala Markandaya's fiction suffers from a serious defect, that is, she has no vision of life. Her characters narrate, describe and generalize but there is no depth and psychological conflict in them. She tells a story but does not proper into the minds of the characters. Internal conflict in a person is seldom presented with skill and dexterity. There is also another defect in her fiction, that is, vagueness and generalization. Her characters are devoid of individuality; for instance, in Nectar in a Sieve Rukmani and Nathan are representatives of uprooted peasants. Like the Shakespearean comedy, Kamala Markandaya's fiction is a woman's world. A fine feminine sensibility pervades her world of fiction. 
Now it will be appropriate to refer to the contemporary poets, critics and novelists regarding their views on Kamala Markandaya's fiction. A.V.Krishna Rao says,

Kamala Markandaya's novels, in comparison with those her contemporary women writers, seem to be more fully reflective of the awakened feminine sensibility in modern India as she attempts to project the image of the changing traditional society. (55)

The theme of Nectar in a Sieve is poverty, starvation and degradation caused by it. Here it is mainly studied in a rural setting, though the theme of urban poverty, exodus and footlessness is also dealt with. The plot of Nectar in a Sieve is easily devisable into two parts-The first part dealing with the life of Rukmani and Nathan in the village, and the second with the life in the city. In the first part of the novel is narrated the story of Rukmani's marriage with Nathan and their best efforts to survive not only the vagaries of nature but also the disturbances wrought by the tannery recently set up near their village. In the second part, it is presented the plight of the couple trying to get accommodation in the city.

The structural scheme of the novel is unveiled to the reader in a flashback technique. According to this scheme the story begins where the novel ends. The novel ends with a tragic, and it seems that the novelist cleverly contrived it in order to elicit the reader's sympathy for the poor and the destitute as Rukmani is. The overall impression of the novel on the reader's mind is that the story is somewhat tempered with and that the pilot has not been allowed to grow naturally.

The Indian culture is basically spiritual and Indians are proud of their cultural heritage. The villagers have a profound, unshakable faith in religion and god. Their view of life is fatalistic. This fatalism and spirit of calm acceptance are seen clearly in Nectar in a Sieve in the lives of the central character. Nathan and Rukmani silently suffer what life inflicts upon them. They do not grumble or complain, but accept silently.

Traditionally the Indian woman accepted the framework of the family with a blind faith and rarely showed a rebellious trend. She continued to be docile self-sacrificing, plaint, loving and capable of suffering. They suffer, submit and adjust themselves to circumstances. Kamala Markandaya has portrayed this aspect of woman's life in Nectar in a Sieve with sensitivity and instinctive understanding.

In general, Kamala Markandaya's novels acknowledge the concrete social, political, and economic barriers that stand in the way of woman's search for empowerment as well as the Andocentric bias that permeates all levels of Hindu-Indian culture. As K.R.Srinivasa Iyengar opines in his Indian writing in English, "Rukmani is symbolic of mother India who is compassion and sufferance who must indeed suffer alt hurts and survive all disasters"(435).

Besides, she deals with the women who are considered to be the weaker sex physically and mentally and they need protection from father, husband and sons at different stages in life. The best way to judge the position of a nation is to find out the status of its women. Woman plays a critical role in every situation. Women in India, especially in the rural areas, are regarded as women within the home and around it. Moving away from the vicinity of home gives them the images of an undesirable character.

The novel, Nectar in a Sieve is the story of peasant woman Rukmani, whose rustic life is distributed by rapid industrialization. As Kamala Markandaya is primarily a humanitarian novelist, her large-heartedness, humanitarian sympathies, abundant kindliness, good nature and generosity are reflected everywhere in her description of the various social problems. Her plot-construction, character portrayal, tragic vision, her study of social manners, and criticism of life is imbued with her humanitarian sympathies. She aims at removing the misery of the poverty-stricken masses in India. The note of distinction pervades her novels. The moral aim of her novels is to get the wrongs of the poor rights. Thus, her novels show her as a crusader for the welfare of humanity.

Mutual love, trust, sympathy, reconciliation and co-operation are the cures for all social evils. Her novel, the rural novel, the domestic novel, and psychological novel, establish her true merit as a social critic. The rural, social and moral picture of modern India that emerges from them serves as an eye-opener to the various faults and flaws found in it. It makes an impassioned plea for practising the nobler values of love, kindness humanity, sympathy, understanding and friendship in their life. Thus giving the persons in ideal human conduct, and laying the foundations of a better and jester, social order in which all strife, misunderstanding, hatred, jealousy, cruelty, enmity, suffering and injustice will yield place to the greatest happiness.

In the day-to-day's life, whenever the news paper is opened in the morning, the interesting cases are obvious - elopement, stealing, rape, etc. Sometimes, these may lead to suicide. But, the important characters of Kamala Markanda try to survive. They accept the fatalism and they do not grumble at all. That is life - full of ups and downs. They have proved it. This is a model for all. In short, the novel is a realistic presentation of the suffering, hunger and starvation, poverty and disease, portrayed of social evils, inter-racial relations, conflict between tradition and modernity, the theme of the east and west encounter, loneliness and exploration of the psyche of man which is the fate of the Indian people even today. Besides, this novel is a representative of her expressions of social condition. Her manifold virtues have made her a great novelist. 


\section{References:}

[1] Arora, Sudhir Kumar, A Study of Kamala Markandaya's Women, New Delhi, Atlantic Publishers Limited, 2006.

[2] Bai, K.Meera, Method and Narrative Techniques in Kamala Markandaya's Nectar in a Sieve, New Delhi, 1991.

[3] Bhatnagar.K.C. Realism in Major Indo-English Fiction, Prakash Book Depot., Bareily,1980.

[4] Bhatnagar, M.K. 'Kamala Markandaya' A Critical Spectrum, Atlantic Publishers Limited, New Delhi, 2002.

[5] Iyengar, K.R. Srinivasa, Indian Writing in English, Sterling Publishers Private Limited, New Delhi, 1983.

[6] Markandaya, Kamala. Nectar in a Sieve, Jaico Publishing House, Mumbai, 1955.

[7] Rao, A.V.Krishna, The Indo-Anglian Novel and the Changing Tradition, Rao and Raghavan, Mysore, 1972. 